\title{
Molecular genetic diversity of seaweeds morphologically related to Ulva rigida at three sites along the French Atlantic coast
}

\author{
Manon Dartois ${ }^{\text {Corresp., } 1}$, Eric Pante ${ }^{\text {Corresp., } 1,2}$, Amélia Viricel ${ }^{1}$, Vanessa Becquet ${ }^{1}$, Pierre-Guy Sauriau ${ }^{1}$ \\ 1 Littoral, Environnement et Sociétés, UMR 7266, CNRS - La Rochelle Université, La Rochelle, France \\ 2 Institut Systématique Evolution Biodiversité (ISYEB), CNRS, Sorbonne Université, EPHE, Université des Antilles, Museum national d'Histoire naturelle, \\ Paris, France \\ Corresponding Authors: Manon Dartois, Eric Pante \\ Email address: manon.dartois0@gmail.com, epante@univ-Ir.fr
}

Foliose species of the genus Ulva are notoriously difficult to identify due to their variable morphological characteristics and high phenotypic plasticity. We reassessed the taxonomic status of several distromatic foliose Ulva spp., morphologically related to Ulva rigida, using DNA barcoding with the chloroplastic tufA and $r b c L$ (for a subset of taxa) genes for 339 selected attached Ulva specimens collected from three intertidal rocky sites. Two of the collection sites were in Brittany and one site was in Vendée, along the Atlantic coast of France. Molecular analyses included several museum specimens and the holotype of Ulva armoricana Dion, Reviers \& Coat. We identified five different tufA haplotypes using a combination of phylogenetic analysis, with the support of several recently sequenced holotypes and lectotypes, and a species delimitation method based on hierarchical clustering. Four haplotypes were supported by validly named species: Ulva australis Areschoug, Ulva fenestrata Postels \& Ruprecht, Ulva lacinulata (Kützing) Wittrock and $U$. rigida $\mathrm{C}$. Agardh. The later was additionally investigated using $r b c \mathrm{~L}$. The fifth haplotype represented exact sequence matches to an unnamed species from European Atlantic coasts. Our results support: (1) the synonymy of both U. rigida sensu Bliding non C. Agardh and $U$. armoricana with $U$. lacinulata. This finding is based on current genetic analysis of tufA from the $U$. armoricana holotype and recent molecular characterization of the lectotype of $U$. laetevirens, which is synonymous to $U$. australis, (2) the presence of $U$. australis as a misidentified introduced species in Brittany, and (3) the presence of $U$. fenestrata and $U$. rigida in southern Brittany. The taxonomic history of each species is discussed, highlighting issues within distromatic foliose taxa of the genus Ulva and the need to genetically characterize all its available type specimens. 
1 Molecular genetic diversity of seaweeds morphologically related to Ulva rigida at three sites 2 along the French Atlantic coast

3 Manon Dartois $^{1}$, Eric Pante ${ }^{1,2}$, Amelia Viricel $^{1}$, Vanessa Becquet ${ }^{1}$, Pierre-Guy Sauriau ${ }^{1}$

$4 \quad{ }^{1}$ Littoral Environnement et Sociétés (LIENSs), UMR 7266, CNRS-La Rochelle Université, 2 rue

5 Olympe de Gouges, F-17000 La Rochelle, France

$6{ }^{2}$ Institut Systématique Évolution Biodiversité (ISYEB), Muséum national d'Histoire naturelle,

7 CNRS, Sorbonne Université, EPHE, Université des Antilles, 43 rue Cuvier, CP 26, 75005 Paris,

8 France

9 Corresponding authors:

10 Manon Dartois

11 Littoral Environnement et Sociétés, 2 rue Olympe de Gouges, F-17000 La Rochelle, France

12 Email address: manon.dartois0@gmail.com

13 Eric Pante

14 Littoral Environnement et Sociétés, 2 rue Olympe de Gouges, F-17000 La Rochelle, France

15 Email address: epante@univ-lr.fr 
Abstract

17 Foliose species of the genus Ulva are notoriously difficult to identify due to their variable morphological characteristics and high phenotypic plasticity. We reassessed the taxonomic status of several distromatic foliose Ulva spp., morphologically related to Ulva rigida, using DNA barcoding with the chloroplastic tufA and $r b c \mathrm{~L}$ (for a subset of taxa) genes for 339 selected attached Ulva specimens collected from three intertidal rocky sites. Two of the collection sites were in Brittany and one site was in Vendée, along the Atlantic coast of France. Molecular analyses included several museum specimens and the holotype of Ulva armoricana Dion, Reviers \& Coat. We identified five different tufA haplotypes using a combination of phylogenetic analysis, with the support of several recently sequenced holotypes and lectotypes, and a species delimitation method based on hierarchical clustering. Four haplotypes were supported by validly named species: Ulva australis Areschoug, Ulva fenestrata Postels \& Ruprecht, Ulva lacinulata (Kützing) Wittrock and U. rigida C. Agardh. The later was additionally investigated using $r b c \mathrm{~L}$. The fifth haplotype represented exact sequence matches to an unnamed species from European Atlantic coasts. Our results support: (1) the synonymy of both $U$. rigida sensu Bliding non $\mathrm{C}$. Agardh and $U$. armoricana with $U$. lacinulata. This finding is based on current genetic analysis of $t u f \mathrm{~A}$ from the $U$. armoricana holotype and recent molecular characterization of the lectotype of $U$. laetevirens, which is synonymous to $U$. australis, (2) the presence of $U$. australis as a misidentified introduced species in Brittany, and (3) the presence of $U$. fenestrata and $U$. rigida in southern Brittany. The taxonomic history of each species is discussed, highlighting issues within distromatic foliose taxa of the genus Ulva and the need to genetically characterize all its available type specimens. 


\section{Introduction}

Macroalgae proliferations in coastal environments fuelled by anthropogenic eutrophication (Fletcher, 1996; Ye et al., 2011) are a worldwide phenomenon (Smetacek \& Zingone, 2013; Wan et al., 2017). Most are composed of species in the genus Ulva (Fletcher, 1996; Jia et al., 2011), leading to the aptly-named 'green tides.' These are composed of free-floating thalli that may become stranded on sheltered areas. Environmental changes affect both pelagic and benthic communities and are detrimental to the ecology, economy, and sanitation of coastal areas (Charlier, Morand \& Finkl, 2008; Ye et al., 2011; Smetacek \& Zingone, 2013). Huge algal biomasses increase sedimentation rates and interfere with oxygen transport. Algae consume oxygen during respiration and create anoxic conditions, followed by the decomposition of algal mats and the development of toxic gaseous sulphur compounds within the stranded biomass (Fletcher, 1996; Charlier, Morand \& Finkl, 2008). Human poisoning and deaths have even been reported following inhalation of hydrogen sulphide (Ménesguen, 2018).

One of the main challenges in green tide studies is to characterize the Ulva species involved. Identifying the species can answer key biological questions, including the level of plurispecificity (Coat et al., 1998; Malta, Draisma \& Kamermans, 1999; Kang et al., 2014; Fort et al., 2020), occurrence of undescribed species (Dion, de Reviers \& Coat, 1998; Lee, Kang \& Kim, 2019), allochthonous/exogeneous specific status (Wolf et al., 2012; Steinhagen, Karez \& Weinberger, 2019), biological mechanisms underlying algal growth (de Casabianca et al., 2002; Fort et al., 2019), and differences between free-floating and attached thalli (Malta, Draisma \& Kamermans, 1999; Han et al., 2013; Zhao et al., 2015). Efforts have been made to describe the Ulva species, provide synopses of reliable morphological and anatomical characteristics, and disentangle taxonomic confusions (Bliding, 1969; Koeman \& van den Hoeck, 1981; Hoeksema \& van den Hoeck, 1983; Phillips, 1988), but misidentification and taxonomic confusion are still common, particularly amongst foliose Ulva species (Loughnane et al., 2008; Kraft, Kraft \& Waller, 2010; Kirkendale, Saunders \& Winberg, 2013; Hughey et al., 2021; Fort et al., 2021b). In some cases, this confusion has led to the coexistence of divergent interpretations of taxa with the same specific epithet, for example, Ulva rigida C. Agardh and Ulva rigida sensu Bliding non C. Agardh. The later species was referred to as Ulva laetevirens Areschoug according to Phillips (1988), and this view was endorsed by numerous studies (Kraft; Kraft \& Waller, 2010; Sfriso, 2010; Cormaci, Furnari \& Alongi, 2014; Mao et al., 2014). This opinion, however, was not widely accepted (Womersley, 1984) as Gallardo et al. (1993), Verlaque, Belsher \& DeslousPaoli (2002) and Loughnane et al. (2008) all argued for further morphological investigation, particularly on type material. New species related to U. rigida sensu Bliding such as Ulva scandinavica Bliding (1969) and Ulva armoricana were described in Europe (Dion, de Reviers \& Coat, 1998).

The use of morphological characteristics alone to identify species in the Ulva genus is often insufficient due to phenotypic plasticity within the genus and the role of associated bacteria on 
76

77

78

79

80

81

82

83

84

85

86

87

88

89

90

91

92

93

94

95

96

97

98

99

100

101

102

103

104

105

106

107

108

109

110

111

112

113

114

115

macroalgal morphogenesis (Alsufyani et al., 2020). Molecular analyses are used in species delineation and phylogenetic studies as alternatives to morphology (Hayden \& Waaland, 2004; Loughnane et al., 2008; Kraft, Kraft \& Waller, 2010), but even these methods are useless unless used in a rigorous taxonomic framework. It has been argued that, based on their morphological and cytological characteristics, the species responsible for local green tides in Brittany during the 1990s include Ulva rotundata Bliding and U. armoricana (Dion, de Reviers \& Coat, 1998). Coat et al. (1998) used molecular analysis to highlight similarities in ITS rDNA sequences between $U$. rotundata from Brittany and material labelled $U$. rigida from Australia. This unanticipated similarity was confirmed by Malta, Draisma \& Kamermans (1999) and was further investigated by Shimada et al. (2003), Hayden et al. (2003), Hayden \& Waaland (2004), and Couceiro, Cremades \& Barreiro (2011), who finally established the conspecificity between ' $U$. rotundata' specimens from Brittany and $U$. australis Areschoug from Australia. In addition, $U$. armoricana may be conspecific with $U$. 'rigida' based on ITS (Malta, Draisma \& Kamermans, 1999; Hayden et al., 2003; Shimada et al., 2003; O'Kelly et al., 2010), ITS combined with $r b c$ L (Hayden \& Waaland, 2004), and $r b c \mathrm{~L}$ alone (Loughnane et al., 2008). Loughnane et al. (2008) and Miladi et al. (2018) also suggested that $U$. rigida C. Agardh and U. laetevirens Areschoug respective specific statuses still require morphological and molecular analyses of type materials to be distinguished. Hughey et al. $(2020,2021)$ provide a convincing answer to the questionable relatedness of $U$. laetevirens with $U$. australis using $r b c \mathrm{~L}$ sequencing. On one hand, they established that $U$. laetevirens is a heterotypic synonym of $U$. australis, based on lectotypes of both taxa (Hughey et al., 2020). On the other hand, Hughey et al. (2021) argued that all published sequences of $U$. laetevirens ( $=U$. rigida sensu Bliding) in gene repositories are erroneously named and should be assigned to U. lacinulata (Kützing) Wittrock. Taxonomic reappraisals can even contribute to the current difficulties in synonymising $U$. armoricana and $U$. scandinavica. Conspecificity with $U$. rigida $\mathrm{C}$. Agardh was the previously accepted view (Brodie, Maggs \& John, 2007), although most molecular studies addressing this hypothesis referred to Bliding (1969) and Phillips' (1988) morphological categorization of U. rigida as $U$. rigida sensu Bliding (Hayden et al., 2003; Shimada et al., 2003; Loughnane et al., 2008; Kraft, Kraft \& Waller, 2010; Kirkendale, Saunders \& Winberg, 2013; Mao et al., 2014; Wan et al., 2017). Conspecificity of $U$. scandinavica with $U$. rigida sensu Bliding (= U. laetevirens) was promoted by Kraft, Kraft \& Waller (2010) and Kirkendale, Saunders \& Winberg (2013) on the basis of molecular analyses.

Molecular analyses, practices, and protocols in DNA-based species identification have been strengthened in several ways: (1) Saunders \& Kucera (2010) recommended the plastid elongation factor tufA instead of ITS rDNA and plastid gene $r b c \mathrm{~L}$ in barcoding green marine macroalgae, (2) large sample sizes guarantee better analytical robustness and intraspecific variability estimates at the population level, and (3) the use of museum-type specimens allow tests of species hypotheses to be unequivocal (Pante et al., 2015, Hughey et al., 2019, 2020, 2021). In fact, the chloroplastic elongation factor tufA marker has been developed for routine barcoding of green marine macroalgae, excluding the Cladophoraceae (Saunders \& Kucera, 2010). Previous 
116 studies on Ulva spp. using tufA suggest that it is variable enough to allow the comparison of 117 intra- and interspecific variation across Ulva species, making it a useful molecular barcode for 118 the genus (Kirkendale, Saunders \& Winberg, 2013; Kang et al., 2014; Miladi et al., 2018; Lee, 119 Kang \& Kim, 2019; Steinhagen, Karez \& Weinberger, 2019). The use of several different

120

121

122

123

124

125

126

127

128

129

130

131

132

133

134

135

136

137

138

139

140

141

142

143

144

145

146

147

148

149

150

151

153

152 Material and methods genetic markers within the Ulva genome (either mitochondrial, chloroplastic or nuclear) nevertheless adds an unexpected difficulty when comparing results and identifying species. For example, $U$. rotundata, which was synonymised as $U$. pseudorotundata Cormaci, G. Furnari \& Alongi, has been identified based on $r b c \mathrm{~L}$ sequencing (Loughnane et al., 2008; Wan et al., 2017) and not on tufA, except for a unique study (Fort et al., 2021a). However, analysis of the $r b c \mathrm{~L}$ sequence of the holotype of $U$. rotundata supports the conclusion that $U$. rotundata is a heterotypic synonym of Ulva lactuca Linnaeus (Hughey et al., 2021). The use of different primers, sequence lengths, and/or the addition of new available specific sequences may result in slight discrepancies between studies. It is worth noting that results based on large sample sizes and datasets (Couceiro, Cremades \& Barreiro, 2011; Kirkendale, Saunders \& Winberg, 2013; Hanyuda et al., 2016; Lee, Kang \& Kim, 2019; Steinhagen, Karez \& Weinberger, 2019), and museum-type material (Hanyuda \& Kawai, 2018; Hughey et al., 2019, 2020, 2021; Steinhagen Karez \& Weinberger, 2019) have contributed significantly to clarifying Ulva spp. taxonomy. The development of organellar (chloroplast and mitochondrion) genome sequencing, combined with species delimitation models, also represent a major step towards a more comprehensive estimate of intra- and interspecific genetic variability (Fort et al., 2021a, b).

We sought to reassess the genetic diversity of foliose Ulva species morphologically related to Ulva rigida sampled from several sites along the French Atlantic coasts. Our approach consisted of a phylogenetic analysis of tufA combined with the chloroplast-encoded $r b c \mathrm{~L}$ gene for a subset of taxa. We also included a large sample size, the type locality of $U$. armoricana in Brittany, and analyses of museum material. We sampled 360 thalli with the macro-morphological

characteristics of foliose $U$. cf. rigida from the intertidal rocky shores of two sites in Brittany and one site in Vendée in the winter. We collected only attached thalli to avoid stranded material as these sites suffer from summer to autumn green tides of free-floating thalli (CEVA, 2015, 2019; Merceron \& Morand, 2004). Our study is the first to include such large numbers of Ulva samples from several sites on the French Atlantic coasts, compared to historical (Coat et al., 1998) or more recent (Fort et al., 2020, 2021a, b) molecular studies. We also analysed the tufA sequence of the U. armoricana holotype collected by Dion, de Reviers \& Coat (1998) at Roscoff (Museum national d'Histoire naturelle, MNHN, Paris, France; voucher MNHN-PC-PC0115137) to clarify the taxonomic relationships between $U$. armoricana and other Ulva species related to $U$. rigida, and confirm synonymies, particularly in view of genetic analyses of the lectotype specimens of U. rigida and U. lacinulata recently provided by Hughey et al. (2021). 
154 Sampling was performed between January $22^{\text {th }}$ and February $21^{\text {st }} 2019$ in the intertidal zone of

155

156

157

158

159

160

161

162

163

164

165

166

167

168

169

170

171

172

173

174

175

176

177

178

179

180

181

182

183

184

185

186

187

188

189

190

191

three sites: La Tranche sur Mer (46 $\left.20^{\prime} 48.6^{\prime \prime} \mathrm{N} 1^{\circ} 25^{\prime} 19.3^{\prime \prime} \mathrm{W}\right)$ in Vendée, Roscoff $\left(48^{\circ} 43^{\prime} 48.1^{\prime \prime} \mathrm{N}\right.$ $\left.3^{\circ} 58^{\prime} 57.7^{\prime \prime} \mathrm{W}\right)$, and Concarneau - Cabellou (47 $\left.51^{\prime} 34.6^{\prime \prime} \mathrm{N} 3^{\circ} 54^{\prime} 47.9^{\prime \prime} \mathrm{W}\right)$ in Brittany (Figure 1). We collected samples during the January/February period to avoid the proliferation of seasonal Ulva population known to occur at these sites (CEVA, 2015, 2019), during which mostly haploid individuals are produced (Potter et al., 2016). This allowed us to capture diploid individuals for further species delimitation using nuclear RAD loci (this project is ongoing). Only attached and whole foliose thalli greater than $7 \mathrm{~cm}^{2}$ were collected from rocky substrates extending over the intertidal zone. Any free-floating thalli from remote intertidal sites or subtidal locations were discarded (Merceron \& Morand, 2004). Field identification was based on green foliose macroalgae matching the macro-morphology of Ulva rigida with large and flat thallus, a bright green colour, and stiff base (Phillips, 1988; Loiseaux-de Goër \& Noailles, 2008; Loughnane et al., 2008; Sfriso, 2010). At each site, more than 200 specimens were collected into individual plastic bags and kept at $4{ }^{\circ} \mathrm{C}$. Each sample was rinsed with filtered seawater in the lab to remove epiphytes and was checked for the presence of stiff basal and rhizoidal regions (Sfriso, 2010), the absence of sporulation or gametogenesis in thallus margins, and the presence of a distromatic blade (observed in transverse sections under a light microscope). We did not consider other cellular criteria (Bliding, 1969; Koeman \& van den Hoeck, 1981; Hoeksema \& van den Hoek, 1983), taking into account their natural variability within and between foliose distromatic Ulva species (Coat et al., 1998; Loughnane et al., 2008; Kraft, Kraft \& Waller, 2010). Approximately 120 specimens per site were collected and preserved at $-80{ }^{\circ} \mathrm{C}$ in individually-numbered plastic bags. Eleven museum samples from the cryptogam collection (PC) of the Muséum national d'Histoire naturelle, Paris (France), including the holotype of U. armoricana (Dion, de Reviers $\&$ Coat, 1998), were added to our samples (Supplemental S1).

\section{DNA extraction and PCR amplifications}

Frozen tissue from the thallus was ground to a powder in liquid nitrogen. Whole genomic DNA was extracted from $0.3 \mathrm{mg}$ samples of the powder using the NucleoSpin Tissue Kit (MachereyNagel). The manufacturer's standard protocols for tissues were followed, except for the following steps: (1) we performed an overnight tissue digestion in proteinase $K$, (2) DNA was eluted in two steps, each with a 3 min incubation with $25 \mu \mathrm{L}$ of $\mathrm{dH}_{2} \mathrm{O}$ pre-heated at $70^{\circ} \mathrm{C}$, for a final volume of $50 \mu \mathrm{L}$. DNA quality and quantity were assessed using a Nanodrop ND-2000 spectrophotometer (Thermo Scientific), a Qubit 1.0 (Thermo Scientific) fluorometer (dsDNA HS Assay Kit), and $1 \mathrm{X}$ agarose gel electrophoresis.

The chloroplast gene tufA was targeted to barcode our specimens. Primers were designed based on Saunders and Kucera (2010) to reduce the number of ambiguities based on the chloroplast genomes available for Ulva in GenBank (Ulva sp. KP720616.1, Ulva flexuosa KX579943.1, NC_035823.1, Ulva prolifera NC_036137.1, KX342867.1, Ulva ohnoi AP018696.1, Ulva lactuca NC_042255.1, MH730972.1, Ulva linza KX058323.1, NC_030312.1 and Ulva fasciata

Peer) reviewing PDF | (2020:09:52855:4:1:NEW 20 Sep 2021) 
192 NC_029040.1, KT882614.1). Primer sequences are shown in Table 1. PCR was carried out using 193 a Sensoquest labcycler with a TaKara ExTaq reaction kit (Takara Bio). PCR amplicons were

194 checked on a 1X agarose gel electrophoresis prior to purification and Sanger sequencing in both 195 forward and reverse directions by Eurofins Genomics (Ebersberg, Germany). Negative controls 196 were performed at the extraction and PCR amplification steps.

197 All tufA sequences (plus one $r b c \mathrm{~L}$ sequence), including sequences from MNHN specimens, were 198 deposited in GenBank (Supplemental S1 and S7).

199

200

201

202

203

204

205

206

207

208

209

210

211

212

213

214

215

216

217

218

219

220

221

222

223

224

225

226

227 228

\section{Data analysis}

Chromatograms were cleaned manually with Geneious Prime 2019.1.2 (www.geneious.com), primer sequences were trimmed, sequences were checked for ambiguities and stop codons. Forward and reverse sequences were then assembled. The final sequence length of the Ulva specimens varied between 807 and 877 bp (Supplemental S1). All tufA sequences produced in this study were aligned to 1,517 available Ulva spp. sequences from GenBank using Muscle 3.8.425 (Edgar, 2004). Three Umbraulva japonica sequences, 14 Umbraulva sp. and one Umbraulva dangeardii were added to constitute an outgroup. Identical sequences from the same species were represented by a single tufA haplotype for further phylogenetic analyses but, when available, holotype or lectotype specimens were highlighted. This resulted in the selection of 139 and four Ulva and Umbraulva haplotypes, respectively. Uncorrected p distances (hereafter called p distances) were calculated using PAUP* v.4.0 (Swofford, 2002) based on the tufA sequences of $774 \mathrm{bp}$ (available on GenBank for Kirkendale, Saunders \& Winberg, 2013), and truncated sequences of $500 \mathrm{bp}$, so as to allow alignment with other Ulva sequences available on GenBank. Truncating the alignment to $500 \mathrm{bp}$ does not change the number of haplotypes within our data set and allows the inclusion of more Ulva species sequences from GenBank. The full tree with 143 sequences was reduced for clarity due to the large number of species included. We excluded species such as Ulva compressa, U. flexuosa, Ulva intestinalis, U. linza, U. prolifera, Ulva stenophylla and Ulva torta to be consistent with our analysis of Brittany and Vendée foliose specimens (Hoeksema \& van den Hoek, 1983; Loiseaux-de Goër \& Noailles, 2008). We also excluded all Ulva sp. not related to our results and reduced the outgroup to only Umbraulva japonica. Our reduced tree (Figure 2) was based on 1,185 sequences ( 80 Ulva sequences and one Umbraulva haplotype as the outgroup) and supported the results from the full dataset (Supplemental S2). Maximum Likelihood tufA trees were inferred for Ulva species using IQTREE 2.0.5 (Nguyen et al., 2015; Minh et al., 2020) with ultrafast bootstrapping (1,000 pseudoreplicates) (Hoang et al., 2018) and a TPM3+F+I+G4 model of evolution (model selection performed using ModelFinder; Kalyaanamoorthy et al., 2017). The resulting trees were edited in Inkscape (https://inkscape.org/).

Species delimitation was performed using Assemble Species by Automatic Partitioning (ASAP; Puillandre, Brouillet \& Achaz, 2020) and the Kimura-2-Parameter model of nucleotide 
229

230

231

232

233

234

235

236

237

238

239

240

241

242

243

244

245

246

247

248

249

250

251

252

253

254

255

256

257

258

259

260

261

262

263

264

265

substitution (Kimura, 1980), which was the closest model to the most likely model selected with ModelFinder. ASAP performs hierarchical clustering on genetic distances to split datasets into species partitions; partitions are attributed a robustness or the asap-score, based on the averaged ranked partition p-values and relative barcode gap width (Puillandre, Brouillet \& Achaz, 2020). ASAP analyses were performed online (https://bioinfo.mnhn.fr/abi/public/asap/) on the $500 \mathrm{bp}$ alignment previously described (80 Ulva haplotypes), and a $774 \mathrm{bp}$ alignment (41 Ulva haplotypes) corresponding to the tufA fragment described by Kirkendale, Saunders \& Winberg (2013). A complementary ASAP analysis was also performed on all available Ulva sp. complete tufA sequences (1,224 bp) from GenBank, which returned 136 non-duplicated records distributed as follows: U. australis (17), U. compressa (7), Ulva expansa (2), Ulva fasciata (1), U. fenestrata (12), U. flexuosa (1), Ulva gigantea (10), U. intestinalis (1), U. lacinulata (38), $U$. lacinulata lectotype from Hvar (Lessina) in Croatia (1), U. lactuca (1), U. linza (1), Ulva mutabilis (1), U. ohnoi (1), Ulva pertusa (1), U. prolifera (1), U. rigida (7), U. rigida lectotype from Cadiz (1), U. rotundata (1), U. sp. A AF-2021 (29) as reported by Fort et al. (2021b) and $U$. sp. (2).

Haplotype richness $(R)$, Shannon's diversity index $(H)$ and Pielou's evenness $(J)$ were calculated using vegan 2.5-4 (Oksanen et al., 2019) in R 3.6.0 (R Core Team, 2020). We used the same package to perform species rarefaction based on sample numbers and fit a Preston's veil model (method: maximized likelihood to $\log 2$ abundances) to our data (sites were pooled, Supplementals S3 and S4) (Preston, 1948; Williamson \& Gaston, 2005). Sampling sites were mapped using R 3.6.0 (Supplemental S6).

\section{Results}

\section{tufA analysis}

tufA was sequenced for 339 of the 360 samples and for three of the 11 MNHN specimens, because of amplification or sequencing difficulties (U. armoricana MNHN-PC-PC0115137, Ulva rigida var. fimbriata J. Agardh MNHN-PC-PC0531492 and U. scandinavica MNHN-PCPC0547277). Five haplotypes were detected based on both the 500 and the $774 \mathrm{bp}$-long sequence alignments. Haplotype 1 was sampled at all sites. Haplotypes 2 and 4 were sampled in Brittany only (Concarneau and Roscoff), while haplotypes 3 and 5 were solely found at Concarneau, and sampled in small numbers i.e. $<10$ thalli (Tables 2 and 3). Concarneau had the highest haplotypic richness $(\mathrm{R}=5)$ and diversity $(\mathrm{H}=1.178)$, followed by $\operatorname{Roscoff}(\mathrm{R}=3, \mathrm{H}=1.095)$ and La Tranche $(\mathrm{R}=1)$, where only the most common haplotype (haplotype 1) was found. The haplotype distribution was even greater in Roscoff $(\mathrm{J}=0.9968)$ than Concarneau $(\mathrm{J}=0.7318)$. Rarefaction suggests that haplotype diversity was accurately estimated, as the rarefaction curve almost reaches an asymptote (Supplemental S3). Preston's Lognormal Model to Abundance Data suggested that 0.05 haplotypes were missed during sampling (5.0538 haplotypes were extrapolated with the method). 
266 The $500 \mathrm{bp}$ alignment based on 80 Ulva haplotypes contained 135 variable sites and 99

267

268

269

270

271

272

273

274

275

276

277

278

279

280

281

282

283

284

285

286

287

288

289

290

291

292

293

294

295

296

297

298

299

300

301

302

303

parsimony-informative sites. No indel was detected (alignment provided as Supplemental S8). On the ML tree, the five haplotypes were aligned with sequences of nominal Ulva species, including available holotype and lectotype sequenced specimens, and Umbraulva japonica (Figure 2, Supplemental S5). To help evaluate the number of nominal species on the basis of genetic divergence, raw p distances were calculated among haplotypes (Table 3). Haplotypes 1 and 2 differed by $1.2 \%$ (six substitutions, half of them being synonymous) and with the three haplotypes with $p$ distances up to $10.4 \%$. Distances between these three haplotypes ranged from $6.8 \%$ to $10.4 \%$ (from 33 to 52 substitutions). Lower p distances were obtained at the $774 \mathrm{bp}$ alignment length with a minimum of $0.9 \%$ between haplotypes 1 and 2 , and a maximum of $9.6 \%$ between haplotypes 2 and 4 .

The five aforementioned haplotypes were distinguished based on phylogenetic analysis, genetic distances, and the ASAP species delimitation analysis. They were distributed within four clades, the first one including two separate sub-clades.

The first clade contained 83 sequences of $U$. lacinulata (including the lectotype specimen from Croatia, MW543061), 30 sequences labelled $U$. 'laetevirens', 14 sequences labelled $U$. 'rigida', 34 sequences identified as Ulva sp. A AF2021 according to Fort et al. (2021b), one sequence from MNHN specimen of $U$. 'rigida var. fimbriata' (MT078957), one sequence from the MNHN specimen of $U$. 'scandinavica' (MT078956), the sequence from the holotype of $U$. armoricana (MT078955), and our haplotypes 1 and 2 (MT078946 and MT078950), supported with a 95\% bootstrap value. Within this clade, $p$ distances ranged from 0 to $1.2 \%$ and the number of substitutions was less than 7. Haplotypes 1 and 2 were bound to separate subclades and were supported with 95 and 99\% bootstrap values. The first subclade contained haplotype 1 (192 sequences), 83 sequences of $U$. lacinulata (including the lectotype) together with MNHN sequences of $U$. armoricana, $U$. 'scandinavica' and $U$. 'rigida var. fimbriata', 30 sequences labelled $U$. 'laetevirens' and 14 sequences labelled $U$. 'rigida', with a p distance ranging from 0 to $0.4 \%$ ( 0 to 2 substitutions). The second subclade presented a $0 \% \mathrm{p}$ distance and clusters haplotype 2 (95 sequences) and 34 sequences identified as $U$. sp. A AF-2021 by Fort et al. (2021b) with MT160688, as a representative sequence. These two subclades were supported by ASAP as two separate species ( 500 bp alignment with 81 haplotypes, asap-score $=2.5$ for 35 specific groups, $\mathrm{P}$-val $=0.166 ; 774 \mathrm{bp}$ alignment with 41 haplotypes, asap-score $=1.5$ for 14 specific groups, $\mathrm{P}-\mathrm{val}=0.097$ ).

The second clade contained one sequence of $U$. 'rotundata', 21 sequences of $U$. rigida including the $U$. rigida lectotype specimen from Cadiz (MW543060) and nine sequences of our haplotype 3 (MT078951), supported with a 100\% bootstrap value. Haplotype 3 presented $0 \%$ p distance with the U. rigida lectotype sequence (MW543060) produced by Hughey et al. (2021). This clade was supported as a single ASAP species partition using both the 500 and $774 \mathrm{bp}$ alignments.

PeerJ reviewing PDF | (2020:09:52855:4:1:NEW 20 Sep 2021) 
304 The third clade contained 181 sequences of $U$. australis, five sequences labelled as $U$. 'pertusa'

305

306

307

308

309

310

311

312

313

314

315

316

317

318

319

320

321

322

323

324

325

326

327

328

329

330

331

332

333

334

335

336

337

338

339

340 and our haplotype 4 (MT078952, MT078953) with 41 sequences. The distance was from 0 to 5 substitutions ( $0.4 \% \mathrm{p}$ distance) and supported with a $100 \%$ bootstrap value. This third clade was supported by ASAP as a single species by both the 500 and 774 bp alignments.

The last clade contained 180 sequences of $U$. 'lactuca', 32 sequences of $U$. fenestrata including the $U$. fenestrata holotype specimen (MK456404) and our haplotype 5 (MT078954). Sequences of this clade were distanced by three substitutions and a $0.6 \% \mathrm{p}$ distance. This clade was supported by ASAP as a single species by both the 500 and 774 bp alignments.

\section{Discussion}

Our Ulva-specific tufA primers allowed the amplification of this barcoding gene for $94 \%$ of sampled specimens but for only $27 \%$ of MNHN material. We identified five haplotypes attributed to nominal foliose Ulva species, and determined that haplotypes 1 and 2 are two distinct species. This determination is based on the General Lineage Concept of species (de Queiroz, 1998), on the analysis of intra- and interspecific genetic distances at tufA (Tables 3 and 4), phylogenetic inference (Figure 2), and the ASAP species delimitation analysis.

On the ML tree (Figure 2), haplotypes 1 and 2 clustered with sequences identified as $U$. armoricana (holotype), U. lacinulata (lectotype), U. 'laetevirens', U. 'rigida', U. 'rigida var fimbriata', $U$. 'scandinavica' (closely matching haplotype 1) and $U$. sp. A AF-2021 (exact matches with haplotype 2 ) with $\mathrm{p}$ distances ranging from 0.4 to $1.4 \%$. This range overlaps with interspecific $\mathrm{p}$ distances of 1.2 to $1.4 \%$ observed between both haplotypes and their nearest neighbour $U$. 'taeniata' (Table 4; 500 bp computations). This supports the view that $\mathrm{p}$ distances of 1.0 to $1.4 \%$ between haplotype 1 and haplotype 2 reflect interspecific diversity (Tables 3 and 4). Kirkendale, Saunders \& Winberg (2013) calculated interspecific distances between 19 Ulva taxa, ranging from $0.65 \%$ (U. ohnoi JN029330 versus $U$. lactuca JN029303) to $5.56 \%$ (U. australis HQ610378 versus $U$. fenestrata HQ610325 as $U$. 'lactuca') based on 774 bp sequences. If we focus on $U$. lacinulata (labelled $U$. 'laetevirens' in the study of Kirkendale, Saunders \& Winberg, 2013), the minimum interspecific divergence is $1.16 \%$ with $U$. lactuca as delimited on 774 bp tufA sequences (Kirkendale, Saunders \& Winberg, 2013). Similarly, we found 1.16\% divergence between $U$. lactuca (MH730972) and our haplotype 1 (Table 4; 774 bp computations). A range of 0.9 to $1.16 \%$ divergence was also estimated between $U$. lacinulata sequences previously labelled U. 'laetevirens' (MT160687 and MT160689) and our haplotype 2. This suggests that our delimited haplotypes 1 and 2, while very close genetically to $U$. lacinulata, represent two distinct species: U. lacinulata and an undescribed species Ulva sp. A, as proposed by Fort et al. (2021b). This interpretation, based on phylogenetics and raw genetic distances, is supported by our results with ASAP, which evaluates intra- and interspecific genetic diversity within a coalescent framework. The complementary ASAP analysis performed on 136 Ulva sp. with complete tufA sequences $(1,224 \mathrm{bp}$ ) returned a partition (best asap-score $=4.0$; $\mathrm{P}$ - 
$341 \mathrm{val}<0.0002,16$ specific groups), which consistently clustered known conspecific taxa such as

342 U. australis/U. pertusa (Couceiro, Cremades \& Barreiro, 2011; Hughey et al., 2020), $U$.

343 compressa/U. mutabilis (Steinhagen et al., 2019), U. lactuca/U. fasciata (Hughey et al., 2019) as

344 three distinct species. ASAP analysis also segregates Ulva sp. A from all other species. This

345 ASAP analysis also supports the view that all tufA sequences (1,224 bp long) previously labelled

$346 U$. 'laetevirens' are molecularly identical or similar to U. lacinulata (MW543306), which is the

347 lectotype specimen provided by Hughey et al. (2021). Consequently, haplotype 1 is considered to

348 be $U$. lacinulata (Kützing) Wittrock, with $U$. armoricana, U. rigida sensu Bliding non C. Agardh

349 and $U$. laetevirens sensu Kraft, Kraft \& Waller (2010) as heterotypic synonyms. Haplotype 2 is

350 considered to be an undescribed species, Ulva sp. A, following Fort et al. (2021b) for specimens

351 collected along the European Atlantic coast (Ireland, UK and Portugal).

352 Haplotype 1: Ulva lacinulata (Kützing) Wittrock 1882

353 The historical background of the description of Ulva lacinulata (Kützing) Wittrock was given by

354 Hughey et al. (2021), revealing various and contradictory opinions on its taxonomy. Genetic

355 analyses using ITS, $r b c \mathrm{~L}$ and tufA of the newly designated lectotype specimen (Herbarium

356 Kützing L 0054997) however provided evidence that most, if not all sequences labelled as $U$.

357 'armoricana', U. 'scandinavica' and U. 'laetevirens' were resolved in the same clade as the

358 lectotype sequence of $U$. lacinulata (Hughey et al., 2021).

359

360

361

362

363

364

365

366

367

368

369

370

371

372

373

374

375

376 Our results highlighted low level of genetic variability amongst tufA sequences of the $U$.

377 lacinulata group (Figure 2). This variability was already noticeable from the results of

Ulva laetevirens was first morphologically described in 1854 (Areschoug, 1854) with Port Philip Bay, Victoria, Australia as its type locality. Areschoug (1854) did not designate a holotype specimen and Womersley (1984) selected one of the two type specimens in Herb. Areschoug as a lectotype (S A2028 is a specimen with a large, expanded and lacerate frond). Womersley (1984) noted that lectotype cells "do not show the characteristics of $U$. rigida" but appear to be a "large, single frond with the cell dimensions and proportions of $U$. australis." Accordingly, he placed $U$. laetevirens as a synonym of $U$. australis, which was not supported by subsequent studies (Phillips, 1988; Kraft, Kraft \& Waller, 2010; Kirkendale, Saunders \& Winberg, 2013), but is today validated by Hughey et al. (2020) following molecular characterisation of the S A2028 lectotype of U. laetevirens. Through investigations of Southern Australian Ulva species, Phillips (1988) suggested that $U$. rigida $\mathrm{C}$. Agardh and $U$. rigida sensu Bliding are two separate species hypotheses, the latter being referred as $U$. laetevirens when compared to Australian specimens (Kraft, Kraft \& Waller, 2010). According to our results, all specimens from haplotype 1, together with a mixture of GenBank sequences labelled $U$. 'laetevirens' and $U$. 'rigida' (Figure 2), did not match $U$. australis sequences (Table 3: 7-8 \% of inter-specific genetic divergence).

Therefore, they are not conspecific with $U$. australis but are fully supported by the $U$. lacinulata lectotype (MW543061). 
378 Kirkendale, Saunders \& Winberg (2013, tufA sequences as U. 'laetevirens'), Miladi et al. (2018, 379 tufA sequences as $U$. 'laetevirens'), Steinhagen, Karez \& Weinberger (2019, tufA sequences as 380 U. 'rigida') and Fort et al. (2021a, sequences labelled as U. 'laetevirens'). The representative 381 sequences of the first subgroup were U. 'laetevirens' HQ610428 (sampled from BC, Canada, but

382

383

384

385

386

387

388

389

390

391

392

393

394

395

396

397

398

399

400

401

402

403

404

405

406

407

408

409

410

411

412

413

414

415 initially labelled $U$. 'rigida' by Saunders \& Kucera, 2010) and JN029322 (sampled from North Brighton in the vicinity of the type locality of $U$. 'laetevirens' at Port Phillip within Port Phillip Bay, Victoria, Australia). This subgroup included sequences labelled U. 'laetevirens' sampled from Connecticut, USA (Mao et al., 2014), the Wadden Sea in Germany (Steinhagen, Karez \& Weinberger, 2019 as seven sequences labelled $U$. 'rigida'), Italy (Wolf et al., 2012 as $U$. 'rigida' HE600178 to HE600182; Milady et al., 2018), and Tunisia (Milady et al., 2018). Representative sequences of the second subgroup were JN029321, JN029324, JN029325 and JN029327 from Australia (Kirkendale, Saunders \& Winberg, 2013). Our 192 analysed sequences of haplotype 1, together with the $3 \mathrm{MNHN}$ sequences of $U$. armoricana (holotype), $U$. 'rigida var fimbriata' and $U$. 'scandinavica', were also included in this subgroup (Figure 2).

The Ulva armoricana holotype specimen MNHN-PC-PC0115137 was collected at Roscoff in 1996 and analysed using ITS with a sequence referred to as 'U. arm.8' (MT078962) by Coat et al. (1998). A Blastn analysis (Zhang et al., 2000) revealed that ' $U$. arm.8' together with the sequence labelled as 'U. arm.2' (MT078963) presented a $99.44 \%$ similarity (3 substitutions of difference) with the ITS sequence of $U$. lacinulata (MW544060) provided by Hughey et al. (2021). Similarly, the $r b c \mathrm{~L}$ sequence of $U$. armoricana holotype (MT078960, Supplemental S1) presented a $99.99 \%$ similarity (one substitution of difference) with the $r b c \mathrm{~L}$ sequence of $U$. lacinulata (MW543061). This confirms that the holotype specimen of $U$. armoricana is identical or nearly identical to $U$. lacinulata using the legacy markers ITS, $r b c \mathrm{~L}$ and $t u f \mathrm{~A}$.

The Ulva 'scandinavica' specimen MNHN-PC-PC0547277 was collected in Brittany by R. Kuhlenkamp and determined following Hoeksema \& van den Hoek (1983). The description of $U$. 'scandinavica' by these authors does not match the concept of $U$. scandinavica given by Bliding (1969) and should be regarded as $U$. rigida sensu Bliding (B. de Reviers, personal communication). Our results support this opinion. Numerous studies have suggested conspecificity between specimens determined as $U$. 'scandinavica' and $U$. 'laetevirens' or $U$. 'rigida', on the basis of ITS (Shimada et al., 2003; Hayden \& Waaland, 2004; Mao et al., 2014), $r b c \mathrm{~L}$ (Loughnane et al., 2008; Wolf et al., 2012; Wan et al., 2017; Hughey et al., 2020), or both ITS and $r b c$ L (Hayden \& Waaland, 2004; Kraft, Kraft \& Waller,2010). Recent molecular analyses of $U$. rigida and $U$. lacinulata lectotype specimens together with $U$. scandinavica material from Bliding have clarified synonymies of these species (Hughey et al., 2021) and support the conspecificity between U. scandinavica and U. lacinulata (Fort et al., 2021b; Hughey et al., 2021).

Ulva rigida var. fimbriata J. Agardh 1883 is regarded by Phillips (1988, p. 440-443) as a synonym of $U$. 'laetevirens' based on the examination of cell conformation in type and holotype 
416 specimens. Our results agree with this assessment, indicating that the specimen U. rigida var. 417 fimbriata MNHN-PC-PC0531492 collected in La Coruna, Spain, belongs to the clade supported 418 by the lectotype specimen of $U$. lacinulata (Figure2). This clade includes several sequences 419 labelled U. 'laetevirens' (Saunders \& Kucera, 2010; Fort et al., 2021a) and/or identified as $U$. 420 lacinulata (Fort et al., 2021b). Ulva rigida var. fimbriata is only reported from the Atlantic 421 coasts of Spain and Portugal (Gallardo et al., 1993; Guiry \& Guiry, 2021). Transverse sections of 422 the basal regions of the thallus of specimens collected from western Portugal (Lima et al., 2017) 423 conform with $U$. 'laetevirens' cell shape descriptions given by Kraft, Kraft \& Waller (2010),

424

425

426

427

428

429

430

431

432

433

434

435

436

437

438

439

440

441

442

443

444

445

446

447

448

449

450

451

452

453 Sfriso (2010) and Mao et al. (2014), with an elongated, narrow, conical shape which is the opposite of the large and rectangular shapes observed in basal regions of $U$. rigida C. Agardh. A molecular characterization of the type specimens located at Lund Herbarium (LD14324 and LD14325) is needed to confirm the heterotypic synonymy with $U$. lacinulata.

Haplotype 2: Ulva sp. A Fort et al. (2021b)

Ulva sp. A is an undescribed species previously labelled as $U$. 'rigida' by Fort et al. (2021a) but separated from $U$. lacinulata by a general mixed yule coalescent model (GMYC) analysis using tufA and ITS1 together with comparison of their respective organellar genomes (Fort et al., $2021 \mathrm{a}, \mathrm{b}$ ). Our ASAP analyses using partial (500 and $774 \mathrm{bp}$ ) and complete 1,224 bp tufA sequences support this view (Table 4 and Supplemental S9). However, no U. lacinulata/U. sp. A separation was noted using $r b c \mathrm{~L}$ (Fort et al., 2021b). This low genetic variability leads Hughey et al. (2021) to suggest conspecificity between $U$. lacinulata and all related $U$. 'rigida'. Both Hughey et al. (2021) and Fort et al. (2021a, b) have used the $r b c \mathrm{~L}$ sequence AY422564 from a Chilean U. 'rigida' specimen (voucher WTU344827 from Pelluco Beach) in their respective analyses of the $U$. lacinulata/U. 'rigida' group. This $r b c \mathrm{~L}$ sequence was used by Fort et al. (2021a) as a reference sequence to specifically support all the sequences labelled $U$. sp. A (Fort et al., 2021b). It is noticeable that the ITS sequence (AY422522) of this voucher, as analysed by Hayden \& Waaland (2004), is 100\% identical to the ITS rDNA sequence (AY260565: ITS15.8S-ITS2 of $515 \mathrm{bp}$ ) of another specimen labelled $U$. 'rigida' (voucher WTU 344826 from the Burke Museum), which was collected from Cadiz (Hayden et al., 2003; Hayden \& Waaland, 2004). Additionally, all the three $U$. 'rigida' sequences (U. rig. 1-3) from specimens collected in Brittany by Coat et al. (1998) have ITS sequences (MT078965, MT078966 and MT078967) identical in ITS to the Spanish $U$. 'rigida' (AY260565). These comparisons using ITS may suggest that the geographic distribution of $U$. sp. A. is larger than previously estimated by Fort et al. (2021b), and include not only Ireland, UK and Portugal but also the Atlantic coast of France and Spain together with the Pacific coast of South America.

Haplotype 3: Ulva rigida C. Agardh 1823

Ulva rigida was described in 1822 by C. Agardh (1823) with a geographic distribution from the Atlantic Ocean (including the Cape of Good Hope) to the Mediterranean and Black Seas. Agardh's son, J.G. Agardh, provided detailed coloured drawings of the cellular morphology of 
454 U. rigida (Agardh, 1883, see his Table IV and figure 19-122). Although C. Agardh did not 455 assign a holotype specimen to the type series placed in LD (Lund Herbarium, Sweden), a 456 lectotype (LD14294) was designated by Papenfuss in 1940 (Papenfuss, 1960, see p. 305 his Plate 4571 and figure 11). His choice was based on one of the two specimens collected by Cabrera on the 458 Atlantic coast of southern Spain. Papenfuss (1960) deduced from Cabrera's practices in 459 phycology that the lectotype came from Cadiz, Spain. According to Ricker (1987), another 460 specimen (LD14449) was independently selected by R.B. Searles in 1975 for lectotypification, 461 but this remained unpublished (Guiry \& Guiry, 2021). The lectotype specimen (LD14294) was 462 molecularly characterised for ITS, $r b c \mathrm{~L}$ and $t u f$ A by Hughey et al. (2021), suggesting that all 463 sequences labelled U. 'pseudorotundata' in Europe are mislabelled and are identical or nearly 464 identical to $U$. rigida.

465 Haplotype 3, with nine samples from Concarneau, presents 22 substitutions (4.4\% p distance) 466 with the closest clade, composed of two sequences of $U$. expansa (Setchell) Setchell \& N.L. 467 Gardner including the holotype specimen (MH730973), and 30 sequences labelled U. 'lobata' 468 (Kützing) Harvey. According to Hughey et al. (2019), these U. 'lobata' sequences sampled in 469 the Northeast Pacific, should be named $U$. expansa because of the synonymy of the $U$. expansa 470 holotype and U. 'lobata' sequences from the northeast Pacific, based on tufA and $r b c \mathrm{~L}$ analyses. 471 The maximum intraspecific $\mathrm{p}$ distance is $0 \%$ for the tufA gene among the 32 GenBank samples 472 of $U$. expansa. The $4.4 \% \mathrm{p}$ distance between these sequences and our haplotype is also too large 473 to consider our haplotype to be within the intraspecific range of $U$. expansa. Haplotype 3 474 clustered with the sequence of the $U$. rigida lectotype together with 21 sequences of $U$. rigida 475 previously labelled U. 'pseudorotundata' collected in Ireland and Portugal by Fort et al. (2019, 476 2021a). To strengthen our taxonomic interpretation of this haplotype, we sequenced a short part 477 of the $r b c \mathrm{~L}$ gene typically used in museum type analyses (Hanyuda \& Kawai, 2018). The Blastn 478 analysis (Zhang et al., 2000) of two samples of our haplotype 3 (MW013545, 238 bp long) 479 revealed a $99.58 \%$ similarity (one substitution of difference) with sequences labelled $U$. 480 'pseudorotundata', $U$. 'rotundata' and the lectotype of U. rigida. Ulva 'pseudorotundata' has 481 been reported in Roscoff as $U$. 'rotundata' (Hoeksema \& van den Hoek, 1983). The synopsis of 482 Hoeksema \& van den Hoek (1983) was used by Coat et al. (1998) in describing ITS sequences of 483 specimens collected at Roscoff in 1994-1995 and morphologically attributed to U. 'rotundata'. It 484 was further demonstrated (vide infra) that these sequences were attributable to $U$. australis

485 (Couceiro, Cremades \& Barreiro, 2011). Consequently, the presence of $U$. rigida at Roscoff (see 486 Dizerbo \& Herpe, 2007; Loiseaux-de Goër \& Noailles, 2008) cannot be confirmed by our results 487 (Table 3). However, the current reports of $U$. rigida in Concarneau may add a new record of the 488 species for southern Brittany (Dizerbo \& Herpe, 2007; Burel, Le Duff \& Ar Gall, 2019). The 489 species has also been described in Ireland in green tide (Wan et al., 2017; Fort, Guiry \& Sulpice, 490 2018) and non-green tide contexts (Fort et al., 2020) as U. 'rotundata' and/or $U$.

491 'pseudorotundata'.

492 Haplotype 4: Ulva australis Areschoug 1854

Peer] reviewing PDF | (2020:09:52855:4:1:NEW 20 Sep 2021) 
493 Haplotype 4 was reported from two sites along the Brittany coasts (Concarneau and Roscoff) and 494 clustered with many sequences of $U$. australis and $U$. pertusa on tufA gene analysis, with a $\mathrm{p}$ 495 distance below $0.4 \%$ on 500 bp. A similar result was obtained by Lee, Kang \& Kim (2019), who 496 determined the intraspecific variation at $t u f \mathrm{~A}$ (ca $800 \mathrm{bp}$ ) in the range $0-0.4 \%$ for $U$. australis 497 from Jeju Island, Korea, within the native distribution area of the species. Kirkendale, Saunders 498 \& Winberg (2013) determined a minimum interspecific divergence of $5.56 \%$ with $U$. fenestrata 499 (as U. 'lactuca') based on $774 \mathrm{bp}$, compared to $6.8 \%$ on our $500 \mathrm{bp}$ for $U$. australis. Based on 500 these values, haplotype 4 presents a $\mathrm{p}$ distance within the intraspecific range of $U$. australis. A 501 complementary comparison of full-length tufA gene sequences (1,224 bp) of $U$. australis and $U$. 502 fenestrata (Hughey et al., 2019; Fort et al., 2021a) revealed that their interspecific genetic 503 distance was limited to 4.6 to $4.7 \%$, based on 56 to 58 SNPs.

504 Ulva australis was described in 1851 at Port Adelaide, South Australia (Areschoug, 1854). 505 Phillips (1988) included $U$. australis within the $U$. rigida C. Agardh taxon based on 506 morphological and developmental characteristics. However, Kraft, Kraft \& Waller (2010) 507 excluded it from this taxon and considered $U$. australis as a species of its own. Kjellman (1897) 508 described U. pertusa from three localities in Japan independent of observations by Areschoug 509 (1854). A more recent comparative study based on the analysis of $r b c \mathrm{~L}$ and ITS1 sequences 510 suggested that $U$. australis from Southern Australia and U. pertusa from Japan are conspecific 511 and widely distributed, as an introduced species, along Iberian coasts (Couceiro, Cremades \& 512 Barreiro, 2011). Ulva pertusa Kjellman is recognised today as a heterotypic synonym of $U$. 513 australis (Guiry \& Guiry, 2021). Molecular analysis of the lectotype of $U$. australis (Hanyuda \& 514 Kawai, 2018) together with one lectotype and two syntypes of U. pertusa (Hughey et al., 2020) 515 supported this synonymy. Hanyuda \& Kawai (2018) further suggested that populations of $U$. 516 australis are non-indigenous in Australia but were introduced from northeast Asia and not 517 directly from Japan by the middle of $19^{\text {th }}$ century. Ulva australis, as U. pertusa, has been 518 reported throughout the world, including the Mediterranean Sea since the early 1970s (Verlaque, 519 Belsher \& Deslous-Paoli, 2002; Hanyuda et al., 2016). This species had been reported in 520 Brittany, at Roscoff, from October 1994 to October 1995 by Coat et al. (1998) as misidentified 521 specimens of $U$. 'rotundata' (Couceiro, Cremades \& Barreiro, 2011) and at Beg Meil, near 522 Concarneau, in 2018 by Fort et al. $(2020,2021 \mathrm{a})$. These authors also reported the species from 523 several Brittany localities (Lannion Bay and Brest), suggesting that $U$. australis may be a 524 common inhabitant of West Brittany coasts and a major contributor to local green tides (Fort et 525 al., 2020). The last synopsis of French records, on the basis of morphology records (Verlaque, 526 Belsher \& Deslous-Paoli, 2002) and molecular data, suggests that this species is largely 527 overlooked along the French Atlantic coasts (Sauriau et al., 2021). At the end of the 20th 528 century, the port of Concarneau was the third biggest tuna fishery port in France (Couliou \& 529 Piriou, 1989) with many ships involved in worldwide tuna fisheries. This makes marine algae 530 communities in the vicinity of Concarneau particularly vulnerable to the introduction of non531 native species such as $U$. australis. 
532 Haplotype 5: Ulva fenestrata Postels \& Ruprecht 1840

533 Haplotype 5 was detected only twice from Concarneau. It clustered with many sequences of $U$.

534 'lactuca' and U. fenestrata, including a sequence from the holotype of U. fenestrata MK456404

535 (Hughey et al., 2019). Uncorrected-p distances range from 0 to $0.6 \%$ with three substitutions.

536 We hypothesize that haplotype 5 belongs to the $U$. fenestrata group considering its p distance of

$5373 \%$ with all U. 'arasakii' sequences (all identical to AB561079, Figure 2).

538 Ulva lactuca has been described by Linnaeus (1753) who did not designate a type specimen. The 539 specimen marked ' 5 ' in the Linnaean herbarium has been recognised as the type U. lactuca by

540 Papenfuss (1960), based on the analysis of the Species Plantarum (Linnaeus, 1753). However,

541 further examination revealed a difference with the modern taxonomic hypothesis for U. lactuca.

542 This specimen had marginal teeth on the thallus margin, unlike the description of the current $U$.

543 lactuca from Europe. Following Papenfuss (1960), Bliding (1969) also identified this type as a

544 sample that may have been collected on the Swedish west coast. This hypothesis was later

545 rejected by Hughey et al. (2019). The U. lactuca holotype was molecularly analysed by Hughey

546 et al. (2019) revealing that the U. lactuca described by Linnaeus is called U. fasciata Delile in

547 the subtropics, and U. lobata in the eastern Pacific Ocean. The lectotype of U. lobata (Kützing)

548 Harvey was renamed U. lactuca (Hughey et al., 2019). These authors also found that European

$549 U$. 'lactuca' $r b c \mathrm{~L}$ sequences clustered with the U. fenestrata Postels \& Ruprecht holotype

550 sampled in eastern Russia, in Avacha Bay. This suggests that all of the 180 U. 'lactuca' tufA

551 sequences within the group of the Ulva fenestrata holotype (MK456404) should be $U$.

552 fenestrata. Many authors have already suggested conspecificity of U. 'lactuca' and U. fenestrata

553 (Hayden et al., 2003; Hayden \& Waaland, 2004; Loughnane et al., 2008). Ulva fenestrata was

554 reported in locations that include the Pacific Ocean, in Washington state (Nelson, Nelson \&

555 Tjoelker, 2003), and in Europe (Hughey et al., 2019). It has been reported in Beg Meil near

556 Concarneau as U. 'lactuca' (Fort et al., 2020) and later as U. fenestrata (Fort et al., 2021a).

557 Indeed, the $r b c \mathrm{~L}$ sequence AB097622 of $U$. 'lactuca' used by these authors was identified as $U$.

558 fenestrata by Hughey et al. (2019).

559 Potential issues with type specimens

560 Careful consideration must be given to GenBank sequences which species names were assigned

561

562

563

564

565

566

567

568 based on morphology. This was previously demonstrated for many Ulva species such as $U$. fasciata, U. fenestrata, U. lactuca, U. laetevirens, U. lobata, U. pertusa, U. spathulata U. stipitata, and U. tenera (Hanyuda \& Kawai, 2018; Steinhagen, Karez \& Weinberger, 2019; Hughey et al., 2019, 2020). Assuming that the tufA gene trees represent species trees within the genus, our study revealed some potential issues with the identification of Ulva sequences on GenBank. For instance, U. 'laetevirens' LT969813 and U. 'rigida' KC661447 do not match any of our haplotypes (Figure 2) and could not be attributed to a validly named species with the support of museum type materials. Similarly, $U$. fasciata sequences are considered to be a 
569 synonym of $U$. lactuca (Hughey et al., 2019) that formed a paraphyletic assemblage along with 570 other taxa. Two sequences of $U$. 'reticulata' identical to MG963806, together with the sequence

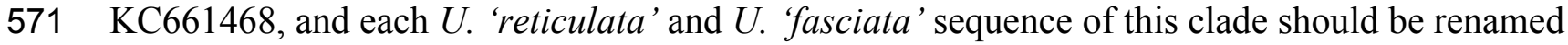
572 U. lactuca based on the $0 \% \mathrm{p}$ distances between U. lactuca MH730972 and the 24 U. fasciata 573 sequences identical to JN029299. All other sequences labelled $U$. 'fasciata' used in our analysis 574 (Figure 2) are thus misidentified. Fort et al. (2021b) provided evidence that misidentification of 575 GenBank sequences is not restricted to a few Ulva species but is inherent to the taxonomic 576 studies of the Ulva genus. Finally, the inclusion of museum types in taxonomic analysis, as 577 previously stated by Loughnane et al. (2008), allows major clarification of the taxonomy of the 578 Ulva genus (Hughey et al., 2019, 2020, 2021). From this point of view, analysis of the holotype

579

580

581

582

583

584

585

586

587

588

589

590

591

592

593

594

595

596

597

598

599

600

601

602

603

604

605

606

607

materials of $U$. gigantea (Kützing) Bliging 1969 (type material located at Lund Herbarium) should strengthen results of further studies of foliose Ulva taxa.

In addition to these taxonomic issues, and as suggested above, lack of resolution of chloroplastic and nuclear-ribosomal molecular markers may cause confusion. What has been identified as intra- and interspecific variation at tufA may not reflect true evolutionary history. There is a strong need to integrate data from the morphology, physiology, ecology, and different types of molecular markers in order to delineate species for this and other taxonomic groups. In Ulva, the sequencing of restriction-site associated DNA (RAD-seq) has proven feasible and produced data that are partially incongruent with $r b c L$ barcoding (Fort, Guiry \& Sulpice, 2018). Similarly, Fort et al. (2021a, b) promoted the use of the complete cytoplasmic genome (mitochondrion and chloroplast) to compare species and estimate intra- and interspecific genetic divergence. Other types of molecular markers, such as trnA-N or atpI-H regions, could provide information on the spatial patterns of genetic diversity and biogeography, as exemplified by $U$. australis on a worldwide scale (Hanyuda et al., 2016) and along the French coasts (Sauriau et al., 2021). These markers may aid in testing the autochthonous/allochthonous status of other Ulva species, particularly for specimens labelled U. 'laetevirens' sensu Kraft, Kraft \& Waller, which may be introduced from Australasia (Kirkendale, Saunders \& Winberg, 2013; Mao et al., 2014). The current synonymy with $U$. lacinulata, as evidenced by Hughey et al. (2021), opens new testable hypotheses since the species was primarily described from the Adriatic Sea (Kützing, 1847).

\section{Conclusions}

This study confirms the presence of five foliose Ulva species that had been misidentified using morphology alone along Brittany and Vendée coasts. These findings are in agreement with those in Fort et al. (2020, 2021a, b), and add some molecular supports for the taxonomic review by Burel et al. (2019). The current report of $U$. australis, which was introduced from north eastern Asia (Hanyuda et al., 2016; Sauriau et al., 2021), is congruent with earlier results by Coat et al. (1998) at Roscoff, Brittany. Identification of $U$. armoricana was challenged by sequencing tufA and $r b c \mathrm{~L}$ markers for the holotype specimen from Roscoff. As a consequence, the status of $U$. armoricana as a heterotypic synonym of the oldest valid name $U$. lacinulata (Kützing) Wittrock is confirmed. Additional sampling during bloom seasons (summer and early fall) will advance

Peer) reviewing PDF | (2020:09:52855:4:1:NEW 20 Sep 2021) 
608 the study of the specific composition of green tides along the French coasts, and the respective 609 roles of these Ulva species in such phenomenon. New investigations using molecular analyses of

610 museum type materials may shed light on these issues.

\section{Acknowledgements}

612 We are grateful to Dr. Bruno de Reviers, Muséum national d'Histoire naturelle (MNHN) Paris, 613 for his advice and comments, and to Nadia Améziane, director of the Marine Station at 614 Concarneau (MNHN) for providing access to the Marine Station laboratory facilities. We also 615 thank Aya Ghedmasi and Salomé Ducos for help with laboratory work, and Fabien Aubert, 616 Valérie Huet and Michel Prineau for help with sampling and laboratory work. We thank Stacy 617 Krueger-Hadfield for her advice on the study. The authors thank the molecular core facility of 618 the LIENSs laboratory and Lionel Kervran of the cryptogam collection of the MNHN, for 619 sampling the herbarium. The authors gratefully acknowledge Marc Costello, Antoine Fort, 620 Giovanni Furnari, Ronan Sulpice, Florian Weinberger, two anonymous reviewers, and the PeerJ 621 copyediting service, whose comments greatly improved our manuscript.

\section{References}

623

624

625

626

627

628

629

630

631

632

633

634

635 636

637 638

639 640
Agardh CA. 1823. Species algarum rite cognitae, cum synonymis, differentiis specificis et descriptionibus succinctis. Volumen primum pars posterior. Lund: Berlingiana. https://img.algaebase.org/pdf/AC100CF118c2219983hHx2C1C128/15932.pdf.

Agardh JG. 1883. Till algernes systematik. Nya bidrag. (Tredje afdelningen). Lunds Universitets Ars-Skrift, Afdelningen för Mathematik och Naturvetenskap 19:1-177. https://img.algaebase.org/pdf/0AC815A5189ce14D6Dqtr16446DD/16061.pdf.

Alsufyani T, Califano G, Deicke M, Grueneberg J, Weiss A, Engelen AH, Kwantes M, Mohr JF, Ulrich JF, Wichard T. 2020. Macroalgal-bacterial interactions: identification and role of thallusin in morphogenesis of the seaweed Ulva (Chlorophyta). Journal of Experimental Botany 71:3340-3349. DOI: 10.1093/jxb/eraa066.

Areschoug JE. 1854. Phyceae novae et minus cognitae in maribus extraeuropaeis collectae. Nova Acta Regiae Societatis Scientiarum Upsaliensis, 3:329-372.

Bliding C. 1969. '1968'. A critical survey of European taxa in Ulvales, Part II. Ulva, Ulvaria, Monostroma, Kornmannia. Botaniska Notiser 121:535-629.

Brodie JA, Maggs CA, John DM. 2007. Green seaweeds of Britain and Ireland. Dunmurry: British Phycological Society, London.

Burel T, Le Duff M, Ar Gall E. 2019. Updated check-list of the seaweeds of the French coasts, Channel and Atlantic Ocean. An aod - les cahiers naturalistes de l'Observatoire marin 7:1-

PeerJ reviewing PDF | (2020:09:52855:4:1:NEW 20 Sep 2021) 
641

642

643

644

645

646

647

648

649

650

651

652

653

654

655

656

657

658

659

660

661

662

663

664

665

666

667

668

669

670

671

672

38. https://www-iuem.univ-brest.fr/observatoire/l-observatoire/ressources/cahiersnaturalistes/AnAod_2019_VII_1_pp_1_38.pdf.

CEVA. 2015. Contrôle de surveillance DCE 2014. Suivi des blooms de macroalgues opportunistes. Pleubian : Centre d'Étude et de valorisation des Algues - Agence de 1'Eau Loire-Bretagne. p 66.

CEVA. 2019. Suivi des blooms de macroalgues opportunistes sur le littoral Loire-Bretagne, Réseau de Contrôle Opérationnel - DCE 2018. Inventaire des marées vertes sur le littoral breton. Pleubian : Centre d'Étude et de valorisation des Algues - Agence de l'Eau LoireBretagne. p 109.

Charlier RH, Morand P, Finkl CW. 2008. How Brittany and Florida coasts cope with green tides. International Journal of Environmental Studies 65:191-208. DOI: 10.1080/00207230701791448.

Coat G, Dion P, Noailles M-C, de Reviers B, Fontaine J-M, Berger-Perrot Y, Loiseaux-de Goër S. 1998. Ulva armoricana (Ulvales, Chlorophyta) from the coasts of Brittany (France). II. Nuclear rDNA ITS sequence analysis. European Journal of Phycology 33:81-86. DOI: 10.1080/09670269810001736563.

Cormaci M, Furnari G, Alongi G. 2014. Flora marina bentonica del Mediterraneo: Chlorophyta. Bollettino delle sedute della Accademia gioenia di scienze naturali in Catania 47:11-436.

Couceiro L, Cremades J, Barreiro R. 2011. Evidence for multiple introductions of the Pacific green alga Ulva australis Areschoug (Ulvales, Chlorophyta) to the Iberian Peninsula. Botanica Marina 54:391-402. DOI: 10.1515/BOT.2011.044.

Couliou J-R, Piriou N. 1989. Concarneau et la pêche thonière tropicale. Norois 144:357-375. www.persee.fr/doc/noroi_0029-182x_1989_num_144_1_4441.

de Casabianca M-L, Barthelemy N, Serrano O, Sfriso A. 2002. Growth rate of Ulva rigida in different Mediterranean eutrophicated sites. Bioresource Technology 82:27-31. DOI: 10.1016/S0960-8524(01)00155-9.

de Queiroz K. 1998. The general lineage concept of species, species criteria, and the process of speciation. In: Howard DJ and Berlocher SH, eds. Endless Forms: Species and Speciation. New York, Oxford University Press:57-75.

Dion P, de Reviers B, Coat G. 1998. Ulva armoricana sp. nov. (Ulvales, Chlorophyta) from the coasts of Brittany (France). I. Morphological identification. European Journal of Phycology 33:73-80. DOI: 10.1080/09670269810001736553. 
673 Dizerbo A, Herpe E. 2007. Liste et répartition des algues marines des côtes françaises de la $674 \quad$ Manche et de l'Atlantique, Iles Anglo-Normandes incluses. Landerneau: Editions 675 ANAXIMANDRE.

676

677

678

679

680

681

682

683

684

685

686

687

688

689

690

691

692

693

694

695

696

697

698

699

700

701

702

703

704

705

706

Edgar RC. 2004. MUSCLE: multiple sequence alignment with high accuracy and high throughput. Nucleic acids research 32:1792-1797. DOI: 10.1093/nar/gkh340.

Fletcher RL. 1996. The occurrence of "Green Tides"- a Review. In: Schramm W and Nienhuis PH, eds. Marine Benthic Vegetation: Recent Changes and the Effects of Eutrophication. Berlin, Heidelberg: Springer Berlin Heidelberg. Ecological Studies 123:7-43. DOI: 10.1007/978-3-642-61398-2_2.

Fort A, Guiry MD, Sulpice R. 2018. Magnetic beads, a particularly effective novel method for extraction of NGS-ready DNA from macroalgae. Algal Research 32:308-313. DOI: 10.1016/j.algal.2018.04.015.

Fort A, Lebrault M, Allaire M, Esteves-Ferreira AA, McHale M, Lopez F, Fariñas-Franco JM, Alseekh S, Fernie AR, Sulpice R. 2019. Extensive variations in diurnal growth patterns and metabolism among Ulva spp. strains. Plant Physiology 180:109-123. DOI: 10.1104/pp.18.01513.

Fort A, Mannion C, Fariñas-Franco JM, Sulpice R. 2020. Green tides select for fast expanding Ulva strains. Science of the Total Environment 698:134337. DOI: 10.1016/j.scitotenv.2019.134337.

Fort A, McHale M, Cascella K, Potin P, Usadel B, Guiry MD, Sulpice R. 2021a. Foliose Ulva species show considerable inter-specific genetic diversity, low intra-specific genetic variation, and the rare occurrence of inter-specific hybrids in the wild. Journal of Phycology 57:219-233. DOI: 10.1111/jpy.13079.

Fort A, McHale M, Cascella K, Potin P, Perrineau M-M, Kerrison PD, da Costa E, Calado R, Domingues MdR, Costa Azevedo I, Sousa-Pinto I, Gachon C, van der Werf A, de Visser W, Beniers JE, Jansen H, Guiry MD, Sulpice R. 2021b. Exhaustive reanalysis of barcode sequences from public repositories highlights ongoing misidentifications and impacts taxa diversity and distribution. Molecular Ecology Resources :1-16. DOI: 10.1111/17550998.13453.

Gallardo T, Garreta AG, Ribera MA, Cormaci M, Furnari G, Giaccone G, Boudouresque CF. 1993. Check-list of Mediterranean Seaweeds. II. Chlorophyceae Wille s.l. Botanica Marina 36:399-422. DOI: 10.1515/botm.1993.36.5.399.

Guiry MD, Guiry GM. 2021. AlgaeBase. World-wide electronic publication, National University of Ireland, Galway. http://www.algaebase.org; searched on 15 January 2021.

Peer) reviewing PDF | (2020:09:52855:4:1:NEW 20 Sep 2021) 
707

708

709

710

711

712

713

714

715

716

717

718

719

720

721

722

723

724

725

726

727

728

729

730

731

732

733

734

735

736

737

738

Han W, Chen L-P, Zhang J-H, Tian X-L, Hua L, He Q, Huo Y-Z, Yu K-F, Shi D-J, Ma J-H, He P-M. 2013. Seasonal variation of dominant free-floating and attached Ulva species in Rudong coastal area, China. Harmful Algae 28:46-54. DOI: 10.1016/j.hal.2013.05.018.

Hanyuda T, Heesch S, Nelson W, Sutherland J, Arai S, Boo SM, Kawai H. 2016. Genetic diversity and biogeography of native and introduced populations of Ulva pertusa (Ulvales, Chlorophyta). Phycological Research 64:102-109. DOI: 10.1111/pre.12123.

Hanyuda T, Kawai H. 2018. Genetic examination of the type specimen of Ulva australis suggests that it was introduced to Australia. Phycological Research 66:238-241. DOI: $10.1111 /$ pre. 12222 .

Hayden HS, Blomster J, Maggs CA, Silva PC, Stanhope MJ, Waaland JR. 2003. Linnaeus was right all along: Ulva and Enteromorpha are not distinct genera. European Journal of Phycology 38:277-294. DOI: 10.1080/1364253031000136321.

Hayden HS, Waaland JR. 2004. A molecular systematic study of Ulva (Ulvaceae, Ulvales) from the northeast Pacific. Phycologia 43:364-382. DOI: 10.2216/i0031-8884-43-4-364.1.

Hoang DT, Chernomor O, von Haeseler A, Minh BQ, Vinh LS. 2018. UFBoot2: Improving the ultrafast bootstrap approximation. Molecular Biology and Evolution 35:518-522. DOI: $10.5281 /$ zenodo.854445.

Hoeksema BW, van den Hoek C. 1983. The taxonomy of Ulva (Chlorophyceae) from the coastal region of Roscoff (Brittany, France). Botanica Marina 26:65-86. DOI: 10.1515/botm.1983.26.2.65.

Hughey JR, Maggs CA, Mineur F, Jarvis C, Miller KA, Shabaka SH, Gabrielson PW. 2019. Genetic analysis of the Linnaean Ulva lactuca (Ulvales, Chlorophyta) holotype and related type specimens reveals name misapplications, unexpected origins, and new synonymies. Journal of Phycology 55:503-508. DOI: 10.1111/jpy.12860.

Hughey JR, Gabrielson PW, Maggs CA, Mineur F, Miller KA. 2020. Taxonomic revisions based on genetic analysis of type specimens of Ulva conglobata, U. laetevirens, U. pertusa and $U$. spathulata (Ulvales, Chlorophyta). Phycological Research 69:148-153. DOI: $10.1111 /$ pre. 12450 .

Hughey JR, Gabrielson PW, Maggs CA, Mineur F. 2021. Genomic analysis of the lectotype specimens of European Ulva rigida and Ulva lacinulata (Ulvaceae, Chlorophyta) reveals the ongoing misapplication of names. European Journal of Phycology :1-11. DOI: 10.1080/09670262.2021.1914862. 
739

740

741

742

743

744

745

746

747

748

749

750

751

752

753

754

755

756

757

758

759

760

761

762

763

764

765

766

767

768

769

Jia S, Wang X, Liu G, Luo D, Zhang J, Liu Y, Lin X, Liu T. 2011. Gene expression analysis of "green tide" alga Ulva prolifera (Chlorophyta) in China. Genes \& Genomics 33:173-178. DOI: $10.1007 / \mathrm{s} 13258-010-0122-6$.

Kalyaanamoorthy S, Minh BQ, Wong TKF, von Haeseler A, Jermiin LS. 2017. ModelFinder: fast model selection for accurate phylogenetic estimates. Nat. Methods, 14:587-589. DOI: $10.1038 /$ nmeth. 4285 .

Kang EJ, Kim J-H, Kim K, Choi H-G, Kim KY. 2014. Re-evaluation of green tide-forming species in the Yellow Sea. Algae 29:267-277. DOI: 10.4490/algae.2014.29.4.267.

Kang JH, Jang JE, Kim JH, Byeon SY, Kim S, Choi SK, Kang YH, Park SR, Lee HJ. 2019. Species composition, diversity, and distribution of the genus Ulva along the coast of Jeju Island, Korea based on molecular phylogenetic analysis. Plos One 14:e0219958. DOI: 10.1371/journal.pone.0219958.

Kimura M. 1980. A simple method for estimating evolutionary rates of base substitutions through comparative studies of nucleotide sequences. Journal of Molecular Evolution 16:111-120. DOI: 10.1007/BF01731581.

Kirkendale L, Saunders GW, Winberg P. 2013. A molecular survey of Ulva (Chlorophyta) in temperate Australia reveals enhanced levels of cosmopolitanism. Journal of Phycology 49:69-81. DOI: 10.1111/jpy.12016.

Kjellman FR. 1897. Marina chlorophyceer från Japan. Bihang til Kongliga Svenska VetenskapsAkademiens Handlingar 23:1-44.

Kjellman FR. 1897. Marina chlorophyceer från Japan [in Swedish]. Stockholm: Norstedt P.A. \& Söner.

Koeman RPT, van den Hoek C. 1981. The taxonomy of Ulva (Chlorophyceae) in the Netherlands. British Phycological Journal 16:9-53. DOI: 10.1080/00071618100650031.

Kraft LGK, Kraft GT, Waller RF. 2010. Investigations into southern Australian Ulva (Ulvophyceae, Chlorophyta) taxonomy and molecular phylogeny indicate both cosmopolitanism and endemic cryptic species. Journal of Phycology 46:1257-1277. DOI: 10.1111/j.1529-8817.2010.00909.x.

Kützing, F.T. (1847). Diagnosen und Bemerkungen zu neuen oder kritischen Algen. Botanische Zeitung, 5: 1-5, 22-25, 33-38, 52-55, 164-167, 177-180, 193-198, 219-223. https://img.algaebase.org/pdf/AC1F0A461137913D07rIDFF68330/4003.pdf. 
770 Lee HW, Kang JC, Kim MS. 2019. Taxonomy of Ulva causing blooms from Jeju Island, Korea

771

772

773

774

775

776

777

778

779

780

781

782

783

784

785

786

787

788

789

790

791

792

793

794

795

796

797

798

799

800

801

802 with new species, U. pseudo-ohnoi sp. nov. (Ulvales, Chlorophyta). Algae 34:253-266. DOI: 10.4490/algae.2019.34.12.9.

Lima AL, Gaspar R, Neto JM, Pereira L. 2017. The identification of macroalgae and the assessment of intertidal rocky shores' ecological statuses in the central western coast of continental Portugal. Chapter 2. In: Newton P, ed. Seaweeds Biodiversity, environmental chemistry and ecological impacts. Hauppauge, New-York: Nova Science Publishers, Inc., 19-84.

Linnaeus C. 1753. Species plantarum, exhibentes plantas rite cognitas, ad genera relatas, cum differentiis specificis, nominibus trivialibus, synonymis selectis, locis natalibus, secundum systema sexuale digestas. Holmiae : Laurentii Salvii.

Loiseaux-de Goër S, Noailles M-C. 2008. Algues de Roscoff. Editions de la Station Biologique de Roscoff.

Loughnane CJ, McIvor LM, Rindi F, Stengel DB, Guiry MD. 2008. Morphology, $r b c$ L phylogeny and distribution of distromatic Ulva (Ulvophyceae, Chlorophyta) in Ireland and southern Britain. Phycologia 47:416-429. DOI: 10.2216/07-61.1.

Malta E-J, Draisma S, Kamermans P. 1999. Free-floating Ulva in the southwest Netherlands: species or morphotypes? A morphological, molecular and ecological comparison. European Journal of Phycology 34:443-454. DOI: 10.1080/09541449910001718801.

Mao Y, Kim JK, Wilson R, Yarish C. 2014. The appearance of Ulva laetevirens (Ulvophyceae, Chlorophyta) in the northeast coast of the United States of America. Journal of Ocean University of China 13:865-870. DOI: 10.1007/s11802-014-2419-6.

Ménesguen A. 2018. Les marées vertes : 40 clés pour comprendre. Editions Quae.

Merceron M, Morand P. 2004. Existence of a deep subtidal stock of drifting Ulva in relation to intertidal algal mat developments. Journal of Sea Research 52:269-280. DOI: 10.1016/j.seares.2004.05.002.

Miladi R, Manghisi A, Armeli Minicante S, Genovese G, Abdelkafi S, Morabito M. 2018. A DNA barcoding survey of Ulva (Chlorophyta) in Tunisia and Italy reveals the presence of the overlooked alien U. ohnoi. Cryptogamie Algologie 39:85-107. DOI: 10.7872/crya/v39.iss1.2018.85.

Minh BQ, Schmidt HA, Chernomor O, Schrempf D, Woodhams MD, von Haeseler A, Lanfear R. 2020. IQ-TREE 2: New models and efficient methods for phylogenetic inference in the genomic era. Mol. Biol. Evol., 37:1530-1534. DOI:10.1093/molbev/msaa015. 
803 Nelson TA, Nelson AV, Tjoelker M. 2003. Seasonal and spatial patterns of "green tides" (ulvoid 804 algal blooms) and related water quality parameters in the coastal waters of Washington 805 State, USA. Botanica Marina 46:263-275. DOI: 10.1515/BOT.2003.024.

806

807

808

809

810

811

812

813

814

815

816

817

818

819

820

821

822

823

824

825

826

827

828

829

830

831

832

833

Nguyen L-T, Schmidt HA, Von Haeseler A, Minh BQ. 2015. IQ-TREE: a fast and effective stochastic algorithm for estimating maximum-likelihood phylogenies. Molecular Biology and Evolution 32:268-274. DOI: 10.1093/molbev/msu300.

O'Kelly CJ, Kurihara A, Shipley TC, Sherwood AR. 2010. Molecular assessment of Ulva spp. (Ulvophyceae, Chlorophyta) in the Hawaiian Islands. Journal of Phycology 46:728-735. DOI: $10.1111 /$ j.1529-8817.2010.00860.x.

Oksanen J, Blanchet FG, Friendly M, Kindt R, Legendre P, McGlinn D, Minchin PR, O'Hara RB, Simpson GL, Solymos P, Stevens, M. H. H. Szoecs E, Wagner H. 2019. vegan: Community Ecology Package. R package version 2.5-4.

Pante E, Puillandre N, Viricel A, Arnaud-Haond S, Aurelle D, Castelin M, Chenuil A, Destombe C, Forcioli D, Valero M, Viard F., Samadi S. 2015. Species are hypotheses: avoid connectivity assessments based on pillars of sand. Molecular Ecology 24:525-544. DOI: 10.1111/mec. 13048 .

Papenfuss GF. 1960. On the genera of the Ulvales and the status of the order. Journal of the Linnean Society of London, Botany 56:303-318. DOI: 10.1111/j.10958339.1960.tb02507.x.

Phillips JA. 1988. Field, anatomical and developmental studies on Southern Australian species of Ulva (Ulvaceae, chlorophyta). Australian Systematic Botany 1:411-456. DOI: 10.1071/SB9880411.

Potter E, Thornber C, Swanson JD, McFarland M. 2016. Ploidy distribution of the harmful bloom forming macroalgae Ulva spp. in Narragansett Bay, Rhode Island, USA, using flow cytometry methods. PLoS ONE 11:1-15. DOI: 10.1371/journal.pone.0149182.

Preston FW. 1948. The commonness, and rarity of species. Ecology 29:254-283. DOI: $10.2307 / 1930989$.

Puillandre N, Brouillet S, Achaz G. 2020. ASAP: assemble species by automatic partitioning. Molecular Ecology Resources 21:609-620. DOI: 10.1111/1755-0998.13281.

R Core Team. 2020. R: A language and environment for statistical computing. $R$ Foundation for Statistical Computing, Vienna, Austria. https://www.R-project.org. 
834 Ricker RW. 1987. Taxonomy and biogeography of Macquarie Island seaweeds. Dorchester: 835 British Museum (Natural History).

836 Saunders GW, Kucera H. 2010. An evaluation of $r b c \mathrm{~L}$, tufA, UPA, LSU and ITS as DNA 837 barcode markers for the marine green macroalgae. Cryptogamie, Algologie 31:487-528.

838 Sauriau P-G, Dartois M, Becquet V, Aubert F, Huet V, Bréret M, Viricel A, Pante E. 2021. 839 Multiple genetic marker analysis challenges the introduction history of Ulva australis (Ulvales, Chlorophyta) along French coasts. European Journal of Phycology 1-13. DOI:

842

843

844

845

846

847

848

849 850

851

852

853

854

855

856

857

858

859

860

861

862

863

864 10.1080/09670262.2021.1876249.

Sfriso A. 2010. Coexistence of Ulva rigida and Ulva laetevirens (Ulvales, Chlorophyta) in Venice Lagoon and other Italian transitional and marine environments. Botanica Marina 53:9-18. DOI: 10.1515/BOT.2010.009.

Shimada S, Hiraoka M, Nabata S, Iima M, Masuda M. 2003. Molecular phylogenetic analyses of the Japanese Ulva and Enteromorpha (Ulvales, Ulvophyceae), with special reference to the free-floating Ulva. Phycological Research 51:99-108. DOI: 10.1046/j.14401835.2003.00296.x.

Smetacek V, Zingone A. 2013. Green and golden seaweed tides on the rise. Nature 504:84-88. DOI: $10.1038 /$ nature12860.

Steinhagen S, Barco A, Wichard T, Weinberger F. 2019. Conspecificity of the model organism Ulva mutabilis and Ulva compressa (Ulvophyceae, Chlorophyta). Journal of Phycology 55:25-36. DOI: 10.1111/jpy.12804.

Steinhagen S, Karez R, Weinberger F. 2019. Cryptic, alien and lost species: molecular diversity of Ulva sensu lato along the German coasts of the North and Baltic Seas. European Journal of Phycology 50:1-18. DOI: 10.1080/09670262.2019.1597925.

Swofford DL. 2002. PAUP*. Phylogenetic Analysis Using Parsimony (* and other methods). Version 4.0b10. Sunderland, MA, USA: Sinauer Associates.

Verlaque M, Belsher T, Deslous-Paoli J-M. 2002. Morphology and reproduction of Asiatic Ulva pertusa (Ulvales, Chlorophyta) in Thau Lagoon (France, Mediterranean Sea). Cryptogamie, Algologie 23:301-310.

Wan AHL, Wilkes RJ, Heesch S, Bermejo R, Johnson MP, Morrison L. 2017. Assessment and characterisation of Ireland's green tides (Ulva species). PLoS ONE12:e0169049. DOI: 10.1371/journal.pone.0169049. 
865 Williamson M, Gaston KJ. 2005. The lognormal distribution is not an appropriate null

866

867

868

869

870

871

872

873

874

875

876

877

878

879

880 hypothesis for the species-abundance distribution. Journal of Animal Ecology 74:409-422.

DOI: 10.1111/j.1365-2656.2005.00936.x.

Wolf MA, Sciuto K, Andreoli C, Moro I. 2012. Ulva (Chlorophyta, Ulvales) biodiversity in the North Adriatic Sea (Mediterranean, Italy): cryptic species and new introductions. Journal of Phycology 48:1510-1521. DOI: 10.1111/jpy.12005.

Womersley HBS. 1984. Handbooks to the flora of South Australia. Adelaide: Woolman, D.J.

Ye N-h, Zhang X-w, Mao Y-z, Liang C-w, Xu D, Zou J, Zhuang Z-m, Wang Q-y. 2011. 'Green tides' are overwhelming the coastline of our blue planet: taking the world's largest example. Ecological Research 26:477-485. DOI: 10.1007/s11284-011-0821-8.

Zhang Z, Schwartz S, Wagner L, Miller W. 2000. A greedy algorithm for aligning DNA sequences. Journal of Computational Biology 7:203-214. DOI: $10.1089 / 10665270050081478$.

Zhao J, Jiang P, Qin S, Liu X, Liu Z, Lin H, Li F, Chen H, Wu C. 2015. Genetic analyses of floating Ulva prolifera in the Yellow Sea suggest a unique ecotype. Estuarine, Coastal and Shelf Science 163:96-102. DOI: 10.1016/j.ecss.2015.05.027. 
Figure 1

Map of sampling sites along the French Atlantic coast (Roscoff and Concarneau in Brittany, and La Tranche sur Mer in Vendée).

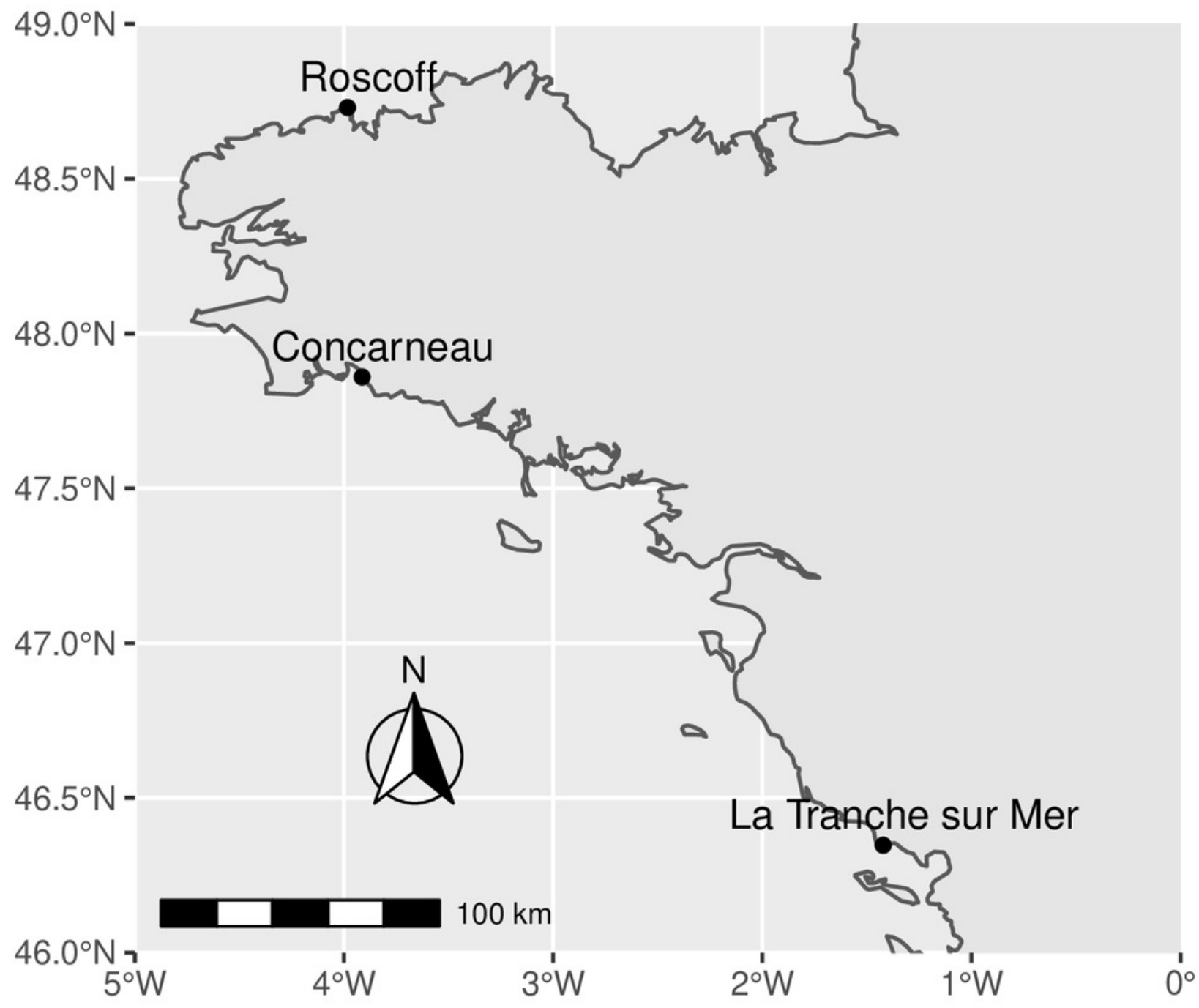


Figure 2

Maximum Likelihood (ML) phylogeny based on 500 bp of the tufA chloroplastic gene.

Haplotypes detected in this study are in bold. Bootstrap support values from the ML analysis are indicated under each node. Sample size, for each haplotype, is presented in brackets. Unit of scale bar: substitution/site. MNHN : Muséum National d'Histoire Naturelle, Paris. Taxon names follow Genbank records, as of the time of publication.

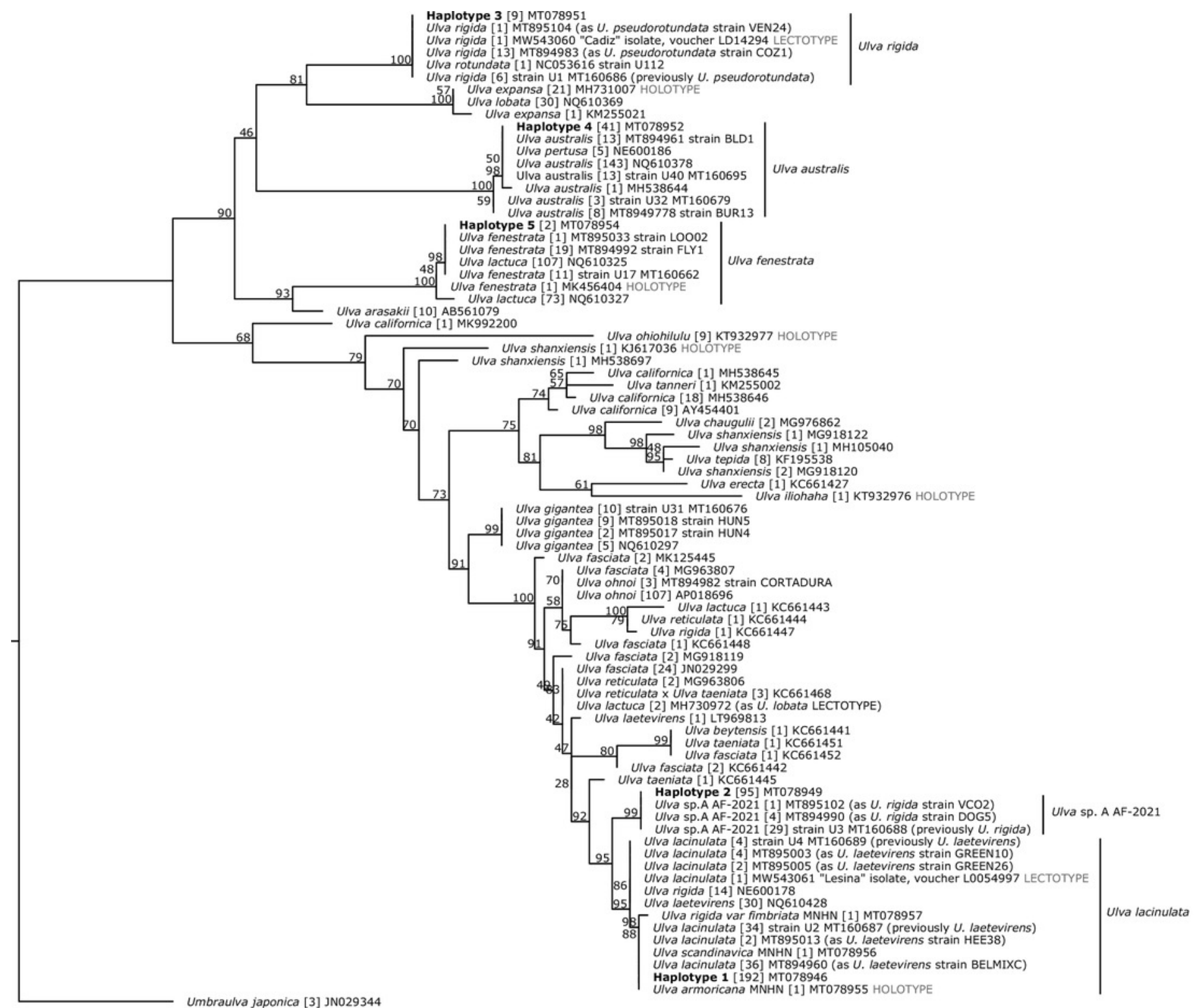




\section{Table 1 (on next page)}

Parameters and sequences of tufA primers, based on Saunders \& Kucera (2010).

Tm: Melting temperature, bp: base-pair. 


\begin{tabular}{|l|l|l|l|}
\hline Primer name & Tm & Sequence (5'-3') & $\begin{array}{l}\text { Expected amplicon } \\
\text { length (bp) }\end{array}$ \\
\hline $\begin{array}{l}\text { tufGF4_MD } \\
\text { (Forward) }\end{array}$ & $58.5^{\circ} \mathrm{C}$ & GGTGCAGCYCAAATGGATGG & 800 \\
\hline $\begin{array}{l}\text { tufAR_MD } \\
\text { (Reverse) }\end{array}$ & $63.3^{\circ} \mathrm{C}$ & CCTTCACGAATTGCAAAACGC & \\
\hline
\end{tabular}

1 
Table 2 (on next page)

Number of samples per haplotype at each site. 


\begin{tabular}{|c|c|c|c|}
\hline & La Tranche s/ Mer & Concarneau & Roscoff \\
\hline Haplotype 1 & 118 & 36 & 38 \\
\hline Haplotype 2 & 0 & 61 & 34 \\
\hline Haplotype 3 & 0 & 9 & 0 \\
\hline Haplotype 4 & 0 & 10 & 31 \\
\hline Haplotype 5 & 0 & 2 & 0 \\
\hline
\end{tabular}

1 


\section{Table 3 (on next page)}

Percent $p$ distances for each pair of tufA haplotypes, for the $500 \mathrm{bp}$ (left value) and 774 bp (right value, in parentheses) alignment lengths. 


\begin{tabular}{|l|l|l|l|l|}
\hline & Haplotype 2 & Haplotype 3 & Haplotype 4 & Haplotype 5 \\
\hline Haplotype 1 & $1.2(0.9)$ & $8.2(7.6)$ & $10.2(9.3)$ & $9.6(8.4)$ \\
\hline Haplotype 2 & & $8.4(7.9)$ & $10.4(9.6)$ & $9.8(8.6)$ \\
\hline Haplotype 3 & & & $6.8(6.5)$ & $6.6(5.2)$ \\
\hline Haplotype 4 & & & & \\
\hline
\end{tabular}

1

2

3 


\section{Table 4(on next page)}

Intra- and interspecific absolute (a) and uncorrected (p) distances for the 500 and 774 alignment lengths.

Closest sequences for the most closely related taxa on the tufA ML tree with sequences representative of all known haplotypes. Data and closest sequence following Kirkendale, Saunders \& Winberg (2013) (\#). Dash ("-"): no $p$ distance estimate due to limited sequence length for $U$. taeniata and $U$. arasakii. 


\begin{tabular}{|c|c|c|c|c|c|c|c|}
\hline \multirow{3}{*}{$\begin{array}{c}\text { Haplotype, } \\
\text { nominal species } \\
\text { (number of sequences) }\end{array}$} & \multicolumn{5}{|c|}{$\begin{array}{l}500 \mathrm{bp} \\
\text { this study }\end{array}$} & \multicolumn{2}{|c|}{$\begin{array}{c}774 \mathrm{bp} \\
\text { this study and } \\
\text { Kirkendale, Saunders \& } \\
\text { Winberg (2013) }\end{array}$} \\
\hline & \multicolumn{2}{|c|}{ Intraspecific } & \multicolumn{5}{|c|}{ Interspecific } \\
\hline & $\mathrm{a}$ & $\mathrm{p}(\%)$ & Closest sequences & $\mathrm{a}$ & $\mathrm{p}(\%)$ & $\mathrm{a}$ & $\mathrm{p}(\%)$ \\
\hline \multirow{3}{*}{$\begin{array}{l}\mathrm{H} 1 \\
\text { U. rigida sensu Bliding } \\
\text { /U. armoricana } \\
(\mathrm{n}=192)\end{array}$} & \multirow{3}{*}{$0-2$} & \multirow[t]{3}{*}{$0-0.4$} & U. taeniata $\mathrm{KC} 661445$ & 6 & 1.2 & $\geq 7$ & - \\
\hline & & & $\begin{array}{l}\text { U. lactuca MH763013, } \\
\text { as \# U. fasciata (JN029299, JN029303) }\end{array}$ & 8 & 1.6 & $9 \#$ & $1.16 \#$ \\
\hline & & & U. rigida $\mathrm{MT} 160688$ & 6 & 1.2 & 7 & 0.9 \\
\hline \multirow{3}{*}{$\begin{array}{l}\mathrm{H} 2 \\
\text { U. rigida C. Agardh } \\
(\mathrm{n}=95)\end{array}$} & \multirow[t]{3}{*}{0} & \multirow[t]{3}{*}{0} & U. taeniata $\mathrm{KC} 661445$ & 7 & 1.4 & $\geq 10$ & - \\
\hline & & & U. lactuca MH763013 & 8 & 1.6 & 9 & 1.16 \\
\hline & & & U. laetevirens MT160687, MT160689 & $5-7$ & $1.0-1.4$ & $7-9$ & $0.9-1.16$ \\
\hline $\begin{array}{l}\mathrm{H} 3 \\
\text { U. pseudorotundata } \\
(\mathrm{n}=9)\end{array}$ & 0 & 0 & U. expansa $\mathrm{MH} 730973$ & 22 & 4.4 & 33 & 4.3 \\
\hline \multirow{3}{*}{$\begin{array}{l}\mathrm{H} 4 \\
\text { U. australis } \\
(\mathrm{n}=41)\end{array}$} & \multirow[t]{3}{*}{$0-2$} & \multirow[t]{3}{*}{$0-0.4$} & U. arasakii $\mathrm{AB} 561079$ & 26 & 5.2 & $\geq 35$ & - \\
\hline & & & U.pseudorotundata MT160686 & 34 & 6.8 & 50 & 6.5 \\
\hline & & & $\begin{array}{l}\text { U. fenestrata MK456404, MT160662, } \\
\text { as \# U. lactuca HQ610325, HQ610327 }\end{array}$ & $35-37$ & $7.0-7.4$ & $43 \#$ & $5.56 \#$ \\
\hline \multirow{3}{*}{$\begin{array}{l}\mathrm{H} 5 \\
\text { U. fenestrata } \\
(\mathrm{n}=2)\end{array}$} & \multirow[t]{3}{*}{$0-3$} & \multirow[t]{3}{*}{$0-0.6$} & U. arasakii $\mathrm{AB} 561079$ & 17 & 3.4 & $\geq 19$ & - \\
\hline & & & $\begin{array}{l}\text { U. australis MH538644, MT160679, } \\
\text { MT160695 }\end{array}$ & $35-37$ & $7.0-7.4$ & $44-45$ & $5.7-5.8$ \\
\hline & & & U.pseudorotundata MT160686 & 33 & 6.6 & 40 & 5.2 \\
\hline
\end{tabular}

